\title{
GENETIC DIVERSITY OF GALIUM CRACOVIENSE EHREND. (RUBIACEAE) - THE POLISH ENDEMIC PLANT
}

\author{
ElŻBieta CieŚlaK, ZBigniEw SZELĄG \\ Institute of Botany, Polish Academy of Sciences \\ Lubicz 46, 31-512 Kraków, Poland \\ e-mail: e.cieslak@botany.pl
}

(Received: October 10, 2008. Accepted: April 25, 2009)

\begin{abstract}
Genetic diversity of Galium cracoviense, a narrow endemic species, limited to the small area in southern Poland and concentrated on Jurassic limestone outcrops near Częstochowa, was examined using the AFLP marker. Twenty nine individuals from three spatially isolated populations were used for the study. AFLP analysis yielded 157 bands, of which $110(70 \%)$ were polymorphic. The AMOVA analysis revealed a substantially higher variation within populations $(89.35 \%)$ than among them $(10.65 \%)$. Values of parameters describing population genetic diversity, such as Shannon index and gene diversity index estimated for each population, were highly similar. The results indicate a high level of genetic polymorphism as well as a high genetic similarity of the isolated populations of $G$. cracoviense and thus an unconstrained gene flow between them. Based on the results we conclude that additional demographic and genetic studies, are necessary to monitor potential decrease of populations size resulting mainly from the mechanical destruction of plants and their habitats caused by intense tourism. Due to the small general range of occurrence, conservation should include the highest possible number of populations of $G$. cracoviense.
\end{abstract}

KEY WORDS: AFLP, Galium cracoviense, gene flow, genetic diversity, isolated populations, narrow endemic species, glacial relicts, Poland.

\section{INTRODUCTION}

The theory of population genetics predicts that small, isolated populations should experience increased random genetic drift, inbreeding and reduced interpopulation gene flow (Wright 1969). This may in turn result in a depletion of genetic diversity within populations, increased genetic divergence among populations, inbreeding depression (Ellstrand and Elam 1993) and reduced fitness to adapt to changing environmental conditions. Such loss of genetic variability and additionally low levels of genetic diversity have been reported for many rare and/or endemic species (Ellstrand and Elam 1993) and have been considered a consequence of rarity (Gitzendanner and Soltis 2000). In this context endemic taxa, due to their restricted distribution, often small population size and narrow ecological amplitudes, are especially vulnerable to extinction (PiękośMirkowa and Mirek 2005). On the other hand, endemic plants in historical time scale, have always been rare with naturally isolated and small populations because of restricted habitat requirements (Holderegger 1997) (e.g. rocky outcrops). Such species groups which are naturally rare in a specific area, occurring in small, isolated populations are defined as "old rare species" (Huenneke 1991; Oostermeijer et al. 1996). In contrast, "new rare species" are species which were formerly much more common in a particular area, and their populations only became smaller, less abundant, and more isolated because of human influence (Huenneke 1991).

Poland has a small number of endemic plant taxa, due to its geographic location and Quaternary geological history. The majority of endemic species occurs in southern Poland in the Carpathians and the Sudeten, which were not covered by the Scandinavian ice sheet during the Pleistocene glaciations. Although formed in the highest ranges of the Carpathians and Sudeten during successive glaciations, local glaciers did not cover entire ridges, which allowed many plant species to survive in situ. The isolated taxonomic position of some Western Carpathian endemic species indicates their advanced phylogenetic age and suggests they may have survived in the Carpathians not only the latest glaciation.

This situation is different in lowland Poland, repeatedly covered by ice sheets during successive Pleistocene glaciations. Only few endemic taxa, classified as neoendemic species, occur in this area. Cochlearia polonica E. Fröhl. 
and Galium cracoviense Ehrend., occurring in the KrakówCzęstochowa Upland (the Polish Jura) in southern Poland, belong to the most widely recognized Polish lowland endemic species.

The Kraków-Częstochowa Upland is a fairly low range formed by Jurassic limestone, with maximum altitude 504 $\mathrm{m}$ a.s.1., stretching ca. $100 \mathrm{~km}$ between Częstochowa and Kraków. It is one of the areas richest in vascular plant species in Poland. Particularly many species are associated with natural saxicolous grasslands Festucetum pallentis (Bąba 2004; Mirek 2004), inhabited also by Galium cracoviense, the focus of this study. A number of dealpine species, such as Allium montanum F. W. Schmidt, Festuca pallens Host, Gymnocarpium robertianum (Hoffm.) Newman, Hieracium bifidum Hornem., H. caesium (Fries) Fries, Polygala brachyptera Chodat, Saxifraga paniculata Mill. and Viola rupestris F. W. Schmidt, that reach the local northern range limit on the limestone rocks in Olsztyn, grow together with Galium cracoviense (Szeląg 2000).

The investigation of population genetic processes or genetic structure in glacial relict plant allows to study the consequences of long term isolation for the genetic diversity of plant populations. An investigation of the genetic diversity within and among glacial relict populations, therefore, can shed light upon population genetic questions of general interest. Additionally, estimation of genetic diversity for this group of species is useful for optimization of sampling strategies and for conservation and research on genetic resources (Hamrick et al. 1991; Schaal et al. 1991; Chalmers et al. 1992).

In the present paper, the AFLP fingerprinting was applied to answer the following questions: (1) What is the effect of the long-term isolation (since the end of the last glaciation) on partitioning of molecular variance and on level of genetic diversity? (2) Are there any geographic differentiation among the populations and different spatial patterns of genetic variability detectable in isolated patches forming the range of Galium cracoviense?

\section{MATERIAL AND METHODS}

\section{Study species}

Galium cracoviense belongs to $G$. sect. Leptogalium Lange, which comprises a complex of polymorphic diploid and polyploid species (Ehrendorfer 1960). The centre of the section's range is located in the mountainous areas of SW Europe. In NE Europe, it is represented only by few endemic species occurring in small areas. G. cracoviense is a diploid and grows only on a few limestone outcrops near the village of Olsztyn (Fig. 1) in the northern part of the Kraków-Częstochowa Upland (Piotrowicz 1958; Ehrendorfer 1960, 1962). It is morphologically most similar to $G$. oelandicum Ehrend., a diploid endemic to Öland island (Ehrendorfer 1960), and the tetraploid G. sudeticum Tausch, which occurs in the Karkonosze Mts. and in the Slavkovský Les hills in the western Czech Republic (Krahulcová and Štěpánková 1998).

\section{Plant material}

After survey of all sites of Galium cracoviense, populations from northern (A), central (B) and southern (C) part of the total geographical range have been selected. This

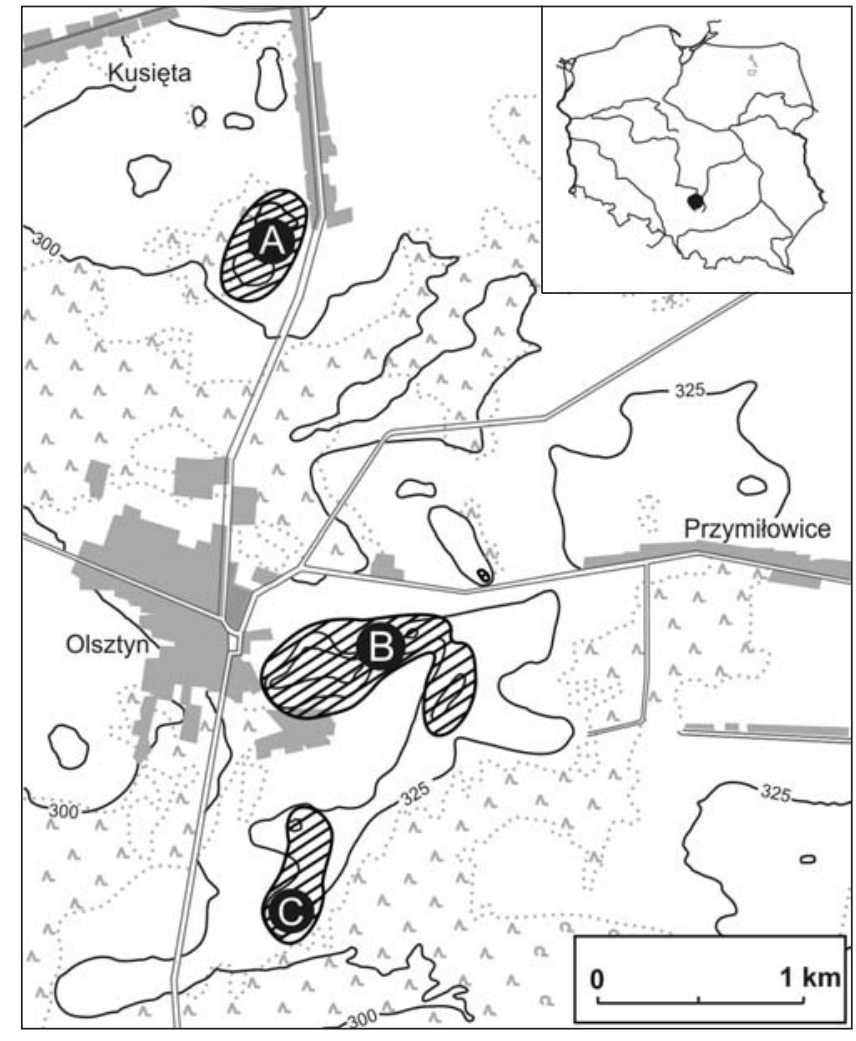

Fig. 1. General distribution of Galium cracoviense Ehrend. (hatched area) and locations of the three studied populations (black points).

sampling reflected the distribution pattern of plants within populations and well represented the distribution of the species in the whole area. Twenty nine samples were collected from the mentioned populations in May 2004 and all of them were used in molecular analysis (Table 1). Samples were collected only from clearly separated clumps of $G$. cracoviense. The way of sampling had to be a hard compromise between optimal statistical approach and conservation needs ( $G$. cracoviense is placed in Polish Red Data Book of Vascular Plants, Mirek 2001). Fragments of young living plants were sampled from 9 to 10 randomly chosen individuals from each population and kept in plastic tubes with silica gel. Samples were stored in the laboratory at $-80^{\circ} \mathrm{C}$ prior to DNA extraction.

\section{DNA extraction and AFLP fingerprinting}

Total DNA was extracted using the DNeasy Plant Mini Kit (Qiagen), according to the manufacturer's protocol, using ca. $10 \mathrm{mg}$ of dried tissue per sampled plant. DNA quality was estimated on $1.2 \%$ agarose gels. AFLP analysis followed the procedure described by Vos et al. (1995) with modification (Cieślak et al. 2007a). DNA was digested with two restriction enzymes: Eco RI and Mse I (New England Biolabs, Inc.). Resulting fragments were ligated to end-specific Eco RI and Mse I double-strand adaptors using T4 DNA Ligase (Roche Diagnostics). Restriction success was verified on $1.5 \%$ agarose gels. The samples were then diluted 1:10 with deionized $\mathrm{H}_{2} \mathrm{O}$. PCR amplification was carried out in two steps: preselective and selective amplification. Preselective amplification was performed using primers with single selective nucleotides: Eco $\mathrm{RI}+\mathrm{A}$ and Mse I + C. PCR products were diluted 1:20. Selective amplification was performed using primers with three selective nucleotides (Eco RI primers were labelled 
TABLE 1. Origin of plant material of Galium cracoviense and estimation of genetic diversity in three populations (A, B, C): N - no. of plants in population; $\mathrm{P}$ - no. of polymorphic bands; $\mathrm{C}$ - no. of private bands; $\mathrm{h}$ - Nei's gene diversity; S - Shannon's information index.

\begin{tabular}{|c|c|c|c|c|c|c|c|}
\hline Population & Collection site & Coordinates & $\mathrm{N}$ & $\mathrm{P}(\%)$ & $\mathrm{C}$ & $\mathrm{h}$ & $\mathrm{S}$ \\
\hline A & Olsztyn, Towarne hill, Poland & $\begin{array}{l}50^{\circ} 46^{\prime} \mathrm{N} \\
19^{\circ} 16^{\prime} \mathrm{E}\end{array}$ & 10 & $59(54 \%)$ & 1 & 0.1479 & 0.2175 \\
\hline B & Olsztyn, Zamkowa hill, Poland & $\begin{array}{l}50^{\circ} 45^{\prime} \mathrm{N} \\
19^{\circ} 16^{\prime} \mathrm{E}\end{array}$ & 10 & $56(51 \%)$ & 1 & 0.1549 & 0.2317 \\
\hline $\mathrm{C}$ & Olsztyn, Biakło hill, Poland & $\begin{array}{l}50^{\circ} 44^{\prime} \mathrm{N} \\
19^{\circ} 16^{\prime} \mathrm{E}\end{array}$ & 9 & $50(45 \%)$ & 4 & 0.1529 & 0.2242 \\
\hline
\end{tabular}

with fluorescent marker FAM 6): Eco RI AAT/Mse I CTA; Eco RI AGT/Mse I CAC; Eco RI ACG/Mse I CAG.

Amplification products were separated in POP 4 polymer with an internal size standard (GeneScan Rox 500) on the ABI Prism 3100-Avant automated sequencer (Applied Biosystems). Three samples were used in duplicates for each analysis as controls, to assess possible genotyping errors (Bonin et al. 2004). Primer screening was conducted on three individuals. Twenty-two selective primer combinations were tested, three of which were chosen for the final analysis (see above). The selection of primer combinations was based on the number of polymorphic fragments and high repeatability. Data were analysed using the GeneScan 1.3 Analysis Software (Applied Biosystems). Good quality fragments were scored in the range of 50-500 bp using Genographer, version 1.6 (Montana State University; http: \hordeum.oscs.montana.edu). Finally, data were assembled in a binary $0 / 1$ matrix.

\section{Data analysis}

Within-population genetic diversity for each population was quantified as (1) percentage of polymorphic loci, (2) Shannon's information index (Lewontin 1972) and (3) gene diversity index (Nei 1978). Additionally, private and discriminating markers were assessed in populations following Cieślak et al. (2007a). Private markers were those specific only to one population, while discriminating markers were private markers present in all samples from the population.

The degree of genetic isolation among populations was estimated by $\mathrm{N}_{\mathrm{m}}$, the number of migrations per generation. $\mathrm{N}_{\mathrm{m}}$, reflecting the effective migration rate among populations, was calculated as follows: $\mathrm{N}_{\mathrm{m}}=\left(1-\mathrm{F}_{\mathrm{ST}}\right) / 4 \mathrm{~F}_{\mathrm{ST}}$ (Wright 1969; Slatkin and Barton 1989) where $\mathrm{F}_{\mathrm{ST}}$ is the proportion of the total genetic diversity among populations (calculated using POPGENE ver. 1.32; Yeh et al. 1997). The UPGMA dendrogram representing genetic relationships among individuals of $G$. cracoviense was constructed on the basis of Jaccard's similarity coefficient (Jaccard 1908). Group support was assessed by bootstrap analysis with 1000 replications (Treecon program, ver. 1.3; van de Peer and de Wachter 1994). Spatial representation of relative similarities between individuals was provided by Principal Coordinates Analysis (PCO). It was performed using MVSP 3.10b software (Kovach 1999).

Data were also analysed with the Bayesian model in Baps 4.14 (Corander et al. 2006). Both a nonadmixture model with uncorrelated allele frequencies and an admixture one with correlation of allele frequencies were used. This Bayesian method detects population structure by clu- stering individuals into panmictic groups assuming Hardy-Weinberg equilibrium and linkage equilibrium within clusters. Both the number of populations in the sample and their allele frequencies are treated as unknown parameters and are jointly estimated by the program. The method does not make use of geographical information for detecting clusters. The procedure was run 70 times each for $\mathrm{K}=1$ to 10 as the assumed maximum number of populations present in the sample. Note that the choice of $K$ is not equal to the number of clusters that is sought in the sample. Instead, the program considers all values equal to or smaller than $\mathrm{K}$ to be a plausible number of clusters.

Genetic structure of populations and variation levels were assessed by the analysis of molecular variance (AMOVA; Excoffier et al. 1992). This analysis was based on the pairwise square Euclidean distance among molecular phenotypes. Significance levels were determined by 1023 permutations. The analysis was conducted at two levels: among groups representing populations and within them. AMOVAs and values of $\mathrm{F}_{\mathrm{ST}}$ were calculated using ARLEQUIN version 2.0 (Schneider et al. 2000; http://lgb.unige.ch/arlequin/).

\section{RESULTS}

Three AFLP primer combinations yielded a total of 157 bands. Of these bands, 110 (70\%) were polymorphic. The number of polymorphic bands in particular populations ranged between 50 (population C) and 59 (population A). None of the populations had discriminating markers, but private markers were present: one per population in A and $\mathrm{B}$ and four in population $\mathrm{C}$. The values of parameters describing genetic diversity estimated for each population were highly similar (Table 1). Calculated values of the gene flow $\left(\mathrm{N}_{\mathrm{m}}\right)$ between populations were relatively high and similar to one another indicating a substantial interchange of genes among populations. The values were as follows: $\mathrm{N}_{\mathrm{mAB}}=3.78 ; \mathrm{N}_{\mathrm{mAC}}=3.35 ; \mathrm{N}_{\mathrm{mBC}}=3.73$. Moreover, AMOVA indicated a substantially higher genetic variation within populations $(89.35 \%)$ than among populations (10.65\%; Table 2) and a low value of fixation index $\mathrm{F}_{\mathrm{ST}}=0.10646$ (Table 3).

The UPGMA cluster analysis demonstrated lack of genetic discontinuities among the populations. None of the spatially isolated groups formed a separate, homogeneous cluster (Fig. 2). PCO scatter diagram (with axes 1 and 2 explaining $12.67 \%$ and $8.8 \%$ of variability, respectively; Fig. 3) showed also that populations formed one complex, although there was a trend for plants growing in population 
TABLE 2. AMOVA analysis results for three populations (groups) and 29 individuals of Galium cracoviense.

\begin{tabular}{lccc}
\hline Source of variation & d.f. & Sum of squares & Variance components \\
\hline Among populations within groups & 2 & 66.610 & 1.84530 \\
Within populations & 26 & 402.700 & 15.48846 \\
\hline Total & 28 & 469.310 & 10.65 \\
89.35 & 17.33376 \\
\hline
\end{tabular}

TABLE 3. Pairwise $\mathrm{F}_{\mathrm{ST}}$ values among study populations. All values are significant at the $\mathrm{p}<0.001$ level.

\begin{tabular}{llll}
\hline Populations & A & B & C \\
\hline A & 0.00000 & & \\
B & 0.10691 & 0.00000 & \\
C & 0.13361 & 0.07686 & 0.00000 \\
\hline
\end{tabular}

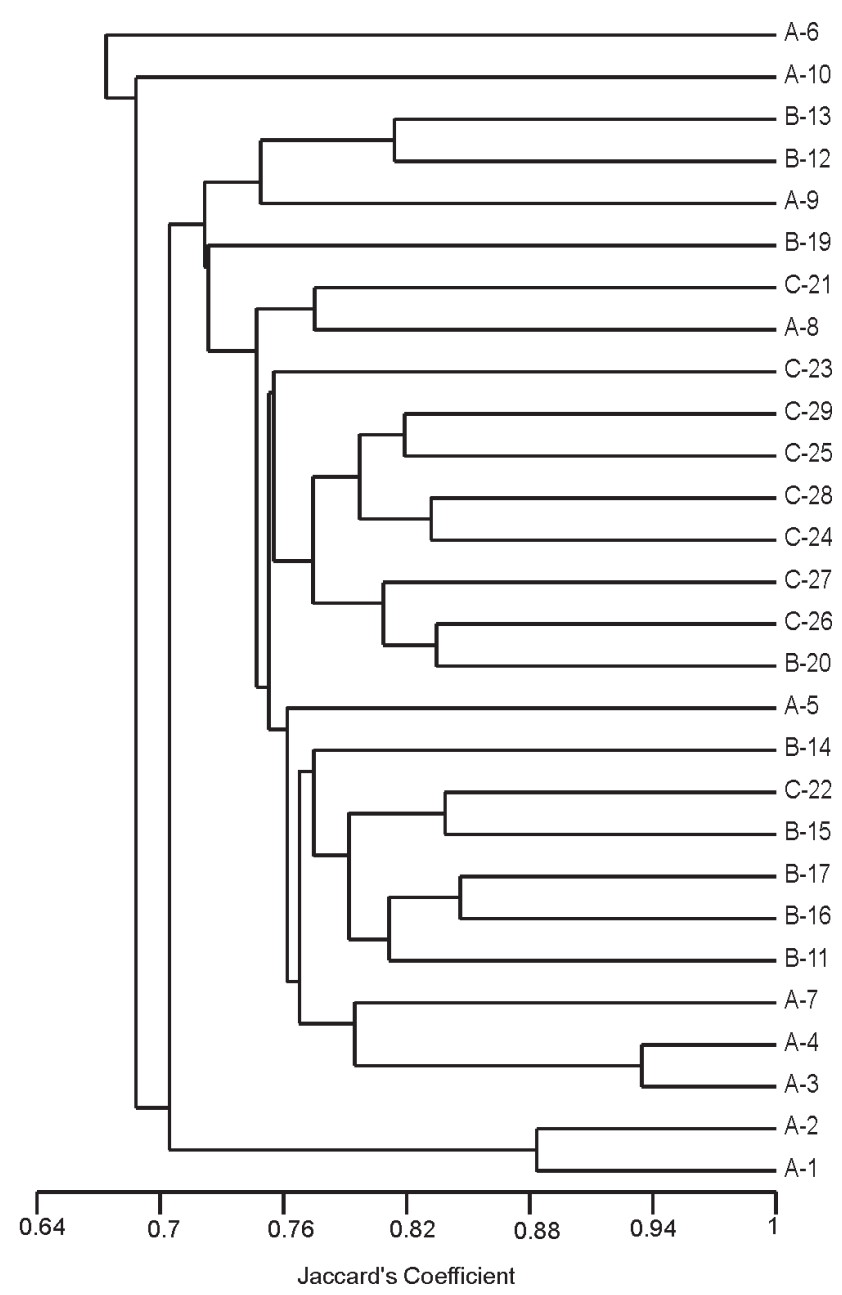

Fig. 2. UPGMA dendrogram based on Jaccard's Coefficient for 29 individuals and three populations (A, B, C) of Galium cracoviense.

A to be located on the right side of the axis 2 (this population is situated in the northernmost part of the geographical range of Galium cracoviense (Fig. 1)), and for plants growing in populations $\mathrm{B}$ and $\mathrm{C}$ to be located at the other extreme in the plot. The weak differentiation was confirmed by the Bayesian analysis. Especially in admixture analysis the highest average likelihood was obtained for $\mathrm{K}=2$ i.e. identifying two groups. However, one of these groups was represented by a single individual (population B, no. 18). Because of its strong genetic divergence from the rest of individuals, it was not included in subsequent analyses. All remaining individuals from $\mathrm{A}, \mathrm{B}$ and $\mathrm{C}$ populations were located in one genetic group.

\section{DISCUSSION}

Our results clearly demonstrate that populations of $\mathrm{Ga}$ lium cracoviense are characterised by a high level of genetic variability. In spite of the fact that investigated populations occur as isolated groups growing on clearly separated rocky outcrops (Fig. 1), they are comparably polymorphic. They are also genetically similar and did not form divergent clusters, showing the distinct spatial isolation of populations. The values of pairwise genetic distances $\left(\mathrm{F}_{\mathrm{ST}}\right)$ between populations were very low and highly significant $(p<0.001$, Table 3$)$ indicating high genetical similarity of all populations. Additionally, the value of gene flow between the populations, calculated on the base of the genetic distances $\left(\mathrm{F}_{\mathrm{ST}}\right)$ within the same localities expressed as the number of individuals migrating between populations per generation (Table 3), showed a high level of migration.

Results of the AMOVA analysis showed that substantially more genetic variation of $G$. cracoviense is distributed within populations than between them (Table 2), indicating a relatively restricted population differentiation, as was expected from outcrossing species. Also the evaluation of $\mathrm{F}_{\mathrm{ST}}$ is close to the values of this parameter reported by authors of the papers analyzing the population structure (though those were often based on data derived both from isozymes and DNA analysis) in mixed and outcrossing species (Loveless and Hamrick 1984; Smith and Pham 1996; Gaudeul el al. 2000; Wróblewska et al. 2003). High genetic homogeneity of the studied populations was also confirmed by the Bayesian analysis.

Such a pattern of genetic variability in small populations and for species with a narrow range has been noted before, for instance in Cochlearia macrorrhiza (Koch et al. 2003), Digitalis minor (Sales et al. 2001), Gentianella austriaca (Greimler and Dobeš 2000), Iris aphylla (Wróblewska and Brzosko 2006) or Seseli farrenyi (López-Pujol et al. 2002). High levels of diversity were demonstrated in the narrow endemic Allium aaseae (Smith and Pham 1996), in the rare and endangered south African shrub Leucadendron elimense (Tansley and Brown 2000), also rare and endangered Leucopogon obtectus (Zawko et al. 2001) and in small populations of endemic Erodium paularense (Martin et al. 1997).

Our results reveal high genetic variability that protects Galium cracoviense against a genetic erosion and potential decrease in genetic diversity. On the other hand, spatially isolated populations (local gene pools) are highly homogeneous (not differentiated) which reduces the species' overall genetic richness and may cause that changes of environmental conditions may have grave consequences both in evolutional and ecological contexts. This low differen- 


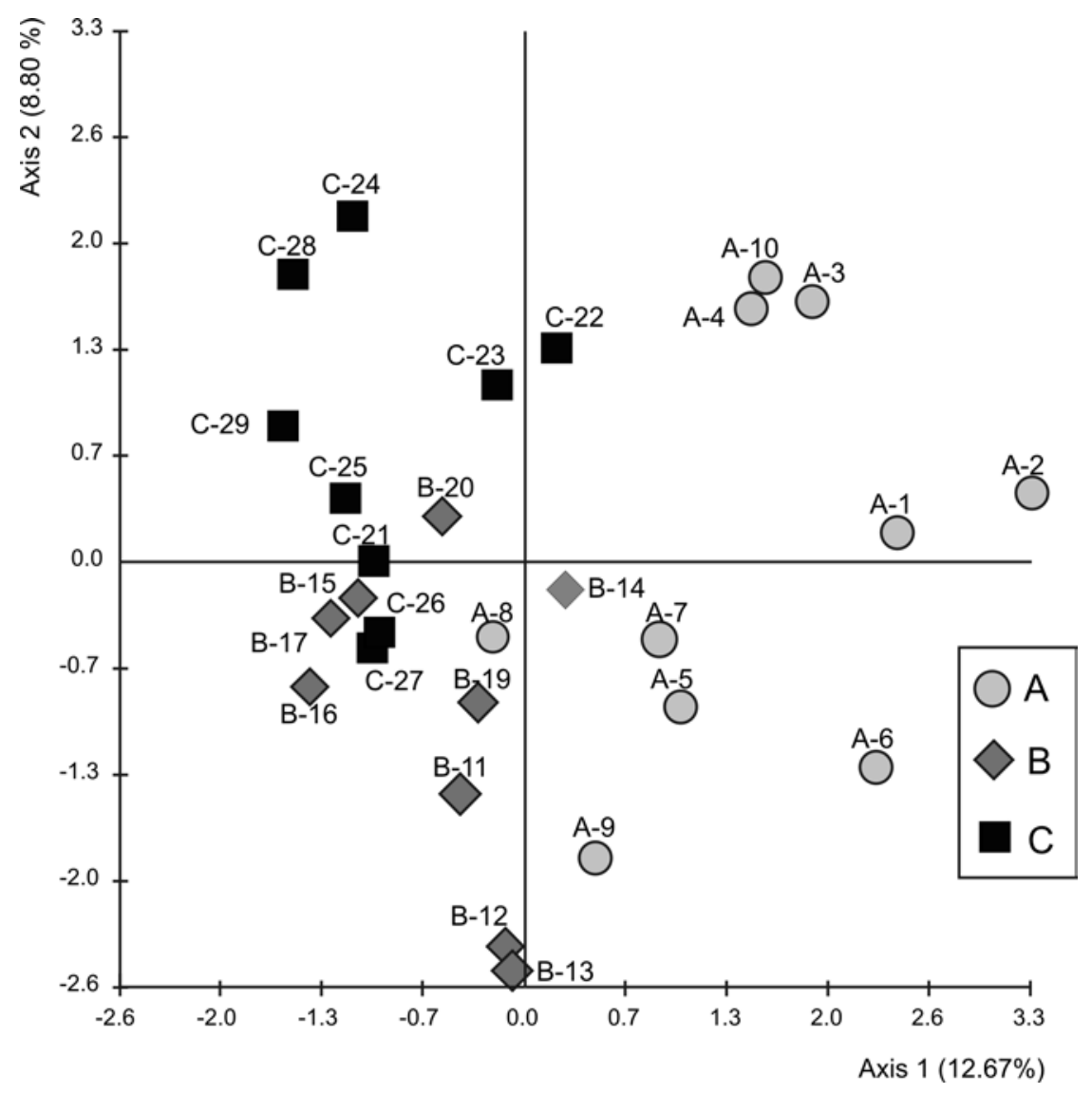

Fig. 3. PCO plot (axis 1 vs. axis 2) of 29 individuals and three populations $(\mathrm{A}, \mathrm{B}, \mathrm{C})$ of Galium cracoviense.

tiation within the whole species range reduces potential ability of the plant to adapt to environmental changes compared to species characterized by having diversified gene pool across their geographical ranges (Ellstrand and Elam 1993). Probably, biogeographical history of the species indicates its stability.

Ehrendorfer (1962) treats Galium cracoviense as a glacial relict that survived at its present locality at least the last glaciation. We share this opinion, however, we believe that the term 'pre-glacial' would be more appropriate. It is highly probable that some of saxicolous calciphilous species, regarded so far as glacial relicts, such as Saxifraga paniculata, Allium montanum, Festuca pallens, Gymnocarpium robertianum, Hieracium bifidum, $H$. caesium and Polygala brachyptera, which grow together with Galium cracoviense, may have also survived in situ at least the last Pleistocene glaciation. The phenomenon of co-occurrence of saxicolous calciphilous glacial and pre-glacial relicts in the same localities in the Apuseni Mountains in Romania was analyzed by Csergö (2002).

The authors base their hypothesis of the ancient, pre-glacial age of Galium cracoviense populations on following premises: 1) the relatively high genetic polymorphism despite very narrow distribution range and small population size could suggest a long-term persistence of such populations in the area and a naturally limited distribution to ecological "islands" of rocky outcrops (Holderegger 1997); 2) the present distribution range of $G$. cracoviense was not covered by the continental ice sheet during the last two glaciations: Wartanian (Riss) and Vistulian (Würm) (Lang 1994; Ber 2005); 3) habitats preferred by G. cracoviense are widely distributed throughout the whole Kraków-Czę- stochowa Upland, however the species occurs exclusively on the northern edge of the Upland, which even during the older and most southward Krznanian (Mindel) glaciation presumably remained free from ice cover and established the local, southern border of the continental ice sheet.

This would be a situation analogous to that observed in Alps, where the stations of many saxicolous alpine endemics are found along the line delimiting maximal range of the lost glaciation's ice sheet (Pitschmann and Reisigl 1959; Prosser and Scortegagna 1998) i.e. places regarded as hypothetical glacial refugia (Schönswetter et al. 2005).

Little is known about the genetic diversity within and among populations of glacial relicts in central Europe (Dannemann 2000; Lutz et al. 2000; Reisch 2002). Numerous studies from North America provide substantial evidence that putative relict plant populations harbour high levels of genetic diversity (Lewis and Crawford 1995; Soltis et al. 1997; Allphin et al. 1998) which suggests, that "old rare species" are better adapted to processes connected with small population size and isolation (Schmidt and Jensen 2000). It seems to be a typical phenomenon, that plants from glacial refugia show high levels of diversity. This allows the species to respond to the selection pressure imposed by pests and disease and to facilitate adaption to future environmental changes (Barrett and Kohn 1991; Holsinger and Gottlieb 1991). The high levels of diversity of glacial relicts in central Europe are present e.g. in Saxifraga paniculata, which also belongs to "old rare species" (Reisch et al. 2003; Reisch and Poschlod 2004; Reisch 2008).

Data on genetic diversity within and among populations of rare and endangered species play a significant role in the formulation of appropriate management strategies directed 
towards their conservation and development, besides being advantageous in the understanding of their structure, evolutionary relationships, taxonomy and demography (Milligan et al. 1994). Consequently, the study of population genetics has been identified as one of the priorities for conservation (Holsinger and Gottlieb 1991).

The present survey was the first attempt to understand the genetic structure of populations of Galium cracoviense. Such data are particularly important for species with narrow ranges and low number of populations, additionally endangered by various external threats, as it is in the case of another Polish endemic plant, Cochlearia polonica where molecular data allowed to confirm the narrow endemic status and estimate the genetic resources of the only existing stable population (Cieślak et al. 2007a, b). In the case of Galium cracoviense additional demographic and molecular studies are necessary to further monitoring in detail of this species' genetic condition (Schwartz et al. 2006). The repeated monitorings of population size indicate a threat mainly by the mechanical destruction of plants and their habitats caused by intense tourism. The decreasing number of individuals in population or number of populations may initiate genetic processes influencing the variability and differentiation of the whole population.

\section{ACKNOWLEDGEMENTS}

We are grateful to the anonymous reviewer for useful comments on earlier drafts of the manuscript. This study was partly supported by the Polish State Committee for Scientific Research (KBN) grant no. 2 P04G 04228.

\section{LITERATURE CITED}

ALLPHIN L., WINDHAM M.D., HARPER K.T. 1998. Genetic diversity and gene-flow in the endangered dwarf poppy, Arctomecon humilis (Papaveraceae). Am. J. Bot. 85: 1251-1261.

BARRETT S.C.H., KOHN J.R. 1991. Genetic and evolutionary consequences of small population sizes in plants: implications for conservation. In: Falk D.A., Holsinger K.E. (eds). Genetics and conservation of rare plants, 3-30. Oxford University Press, Oxford.

BĄBA W. 2004. The species composition and dynamics in wellpreserved and restored calcareous xerotermic grasslands (South Poland). Biologia, Bratislava 59: 447-456.

BER A. 2005. Polish Pleistocene stratigraphy. A review of interglacial stratotypes. Netherl. J. Geosc. 84: 61-76.

BONIN A., BELLEMAIN E., BRONKEN EIDESEN P., POMPANON F., BROCHMANN C., TABERLET P. 2004. How to track and assess genotyping errors in population genetic studies. Mol. Ecol. 13: 3261-3273.

CIEŚLAK E., RONIKIER M., KOCH M.A. 2007a. Western Ukrainian Cochlearia (Brassicaceae) - the identity of an isolated edge population. Taxon 56: 112-118.

CIEŚLAK E., KORBECKA G., RONIKIER M. 2007b. Genetic structure of the critically endangered endemic Cochlearia polonica (Brassicaceae): efficiency of the last-chance transplantation. Bot. J. Linn. Soc. 155: 527-532.

CHALMERS K.J., WAUGH R., SPRENT J.A., POWELL W. 1992. Detection of genetic variation between and within populations of Gliricidia sepium and G. maculata using RAPD markers. Heredity 69: 465-472.
CORANDER J., MARTTINEN P., MÄNTYNIEMI S. 2006. A Bayesian method for identification of stock mixtures from molecular marker data. Fish. Bull. 104: 550-558.

CSERGÖ A.-M. 2002. The problem of the refugia of certain preglacial and glacial relict populations from the calciphilous flora of the Apuseni Mountains (Romania). Contribuţii Botanice 37: 251-262.

DANNEMANN A. 2000. Der Einfluss von Fragmentierung und Populationsgröße auf die genetische Variation und Fitness von seltenen Pflanzenarten am Beispiel von Biscutella laevigata (Brassicaceae). Dissertationes Botanicae, 330. J. Cramer, Berlin, Stuttgart.

EHRENDORFER F. 1960. Neufassung der Sektion Lepto-Galium Lange und Beschreibung neuer Arten und Kombinationen. Sitzungsber. Österr. Akad. Wissensch. Math.-nat. Kl., Abt. I 169(9/10): 407-421.

EHRENDORFER F. 1962. Cytotaxonomische Beiträge zur Genese der mitteleuropäischen Flora und Vegetation. Ber. Deutsch. Bot. Gesell. 75: 137-152.

ELLSTRAND N.C., ELAM D.R. 1993. Population genetic consequences of small population size: implications for plant conservation. Annu. Rev. Ecol. Syst. 24: 217-242.

EXCOFFIER L., SMOUSE P.E., QUATTRO J.M. 1992. Analysis of molecular variance inferred from metric distances among DNA haplotypes: application to human mitochondrial DNA restriction data. Genetics 131: 479-491.

GAUDEUL M., TABERLET P., TILL-BOTTRAUD I. 2000. Genetic diversity in an endangered alpine plant, Eryngium alpinum L. (Apiaceae), inferred from amplified fragment length polymorphism marker. Mol. Ecol. 9: 1625-1637.

GITZENDANNER M.A., SOLTIS P.S. 2000. Patterns of genetic variation in rare and widespread plant congeners. Am. J. Bot. 87: 783-792

GREIMLER J., DOBEŠ C. 2000. High genetic diversity and differentiation in relict lowland populations of Gentianella austriaca (A. and J. Kern.) Holub (Gentianaceae). Plant Biol. 2: 628-637.

HAMRICK J.I., GODL M.J.W., MURAWLKI D.A., LOLELESS M.D. 1991. Correlations between species traits and allozyme diversity. In: Falk D.A., Holsinger K.E. (eds). Genetics and conservation of rare plants, 75-86. Oxford University Press, Oxford.

HOLDEREGGER R. 1997. Recent perspectives in conservation biology of rare plants. Bulletin of the Geobotanical Institute ETH 63: 109-116.

HOLSINGER K.E., GOTTLIEB L.D. 1991. Conservation of rare and endangered species: principles and prospects. In: Falk D.A., Holsinger K.E. (eds). Genetics and conservation of rare plants, 195-208. Oxford University Press, Oxford.

HUENNEKE L.F. 1991 Ecological implications of genetic variation in plant populations. In: Falk D.A., Holsinger K.E. (eds). Genetics and conservation of rare plants, 31-44. Oxford University Press, Oxford.

JACCARD P. 1908. Nouvelles recherches sur la distribution florale. Bul. Soc. Vaudoise Sci. Nat. 44: 223-270.

KOCH M., DOBEŠ C., BERNHARDT K.G., KOCHJAROVÁ J. 2003. Cochlearia marcorrhiza (Brassicaceae): a bridging species between Cochlearia taxa from the Eastern Alps and the Carpathians? Pl. Syst. Evol. 242: 137-147.

KOVACH W.L. 1999. MVSP - A multi-variate statistical package for Windows, ver. 3.1. Kovach computing Services, Penthraeth.

KRAHULCOVÁ A., ŠTĚPÁNKOVÁ J. 1998. Serpentine and polyploid differentiation within Galium pumilum agg. (Rubiaceae) in Eastern C. Europe. Folia Geobot. 33: 87-102.

LANG G. 1994. Quartäre Vegetationsgeschichte Europas. Methoden und Ergebnisse. Gustav Fischer Verlag, Jena, Stuttgart, New York.

LEWIS P.O., CRAWFORD D.J. 1995. Pleistocene refugium endemics exhibit greater allozymic diversity than widespread 
congeners in the genus Polygonella (Polygonaceae). Am. J. Bot. 82: 141-149.

LEWONTIN R.C. 1972. The apportionment of human diversity. Evol. Biol. 6: 381-398.

LOVELESS M.D., HAMRICK J.L. 1984. Ecological determinants of genetic structure in plant populations. An. Rev. Ecol. and Syst. 15: 65-95.

LUTZ E., SCHNELLER J., HOLDEREGGER R. 2000. Understanding population history for conservation purposes: Population genetics of Saxifraga aizoides (Saxifragaceae) in the lowlands and the lower mountains north of the Alps. Am. J. Bot. 87: $583-590$

LÓPEZ-PUJOL J., BOSCH M., SIMON J., BLANCHÉ C. 2002. Allozyme variation and population structure of the very narrow endemic Seseli farrenyi (Apiaceae). Bot. J. Linn. Soc. 138: 305-314.

MARTIN C., GONZALEZ-BENITO M.E., IRIONDO J.M. 1997. Genetic diversity within and among populations of a threatened species: Erodium paularense Fern. Gonz. \& Izco. Mol. Ecol. 6: 813-820.

MILLIGAN B.G., LEEBENS-MACK J., STRAND A.E. 1994. Conservation genetics: beyond the maintenance of marker diversity. Mol. Ecol. 3: 423-435.

MIREK Z. 2001. Galium cracoviense Ehrend. Przytulia małopolska. In: Kaźmierczakowa R., Zarzycki K. (eds). Polska Czerwona Księga Roślin. Paprotniki i rośliny kwiatowe. Polska Akademia Nauk: Instytut Botaniki im. W. Szafera, Instytut Ochrony Przyrody, Kraków. (in Polish with English summary)

MIREK Z. 2004. Galium cracoviense Ehrend. Przytulia krakowska, przytulia małopolska. In: Sudnik-Wójcikowska B., Werblan-Jakubiec H. (eds). Gatunki roślin. Poradnik ochrony siedlisk i gatunków Natura 2000 - podręcznik metodyczny. Vol. 9, 125-127. Ministerstwo Środowiska, Warszawa. (in Polish)

NEI M. 1978. Estimation of average heterozygosity and genetic distance from a small number of individuals. Genetics 89: 583-590.

OOSTERMEIJER J.G.B., BERHOLZ A., POSCHLOD P. 1996 Genetical aspects of fragmented plant populations. In: Settele J., Margules C., Poschlod P., Henle K. (eds). Species survival in fragmented landscapes, 93-101. Kluwer, Dordrecht.

PIĘKOŚ-MIRKOWA H., MIREK Z. 2005. Endemic vascular plants in the Polish Carpathians - threat and conservation. Nature Conservation 61: 1-8.

PIOTROWICZ M. 1958. Caryological studies in some species of the genus Galium L. Acta Biol. Cracov. Ser. Bot. 1: 159-169.

PITSCHMANN H., REISIGL H. 1959. Endemische Blütenpflanzen der Südalpen zwischen Luganersee und Etsch. Veröff. Geobot. Inst., Rübel, Zürich. 35: 44-68.

PROSSER F., SCORTEGAGNA S. 1998. Primula recubariensis, a new species of Primula sect. Auricula Duby endemic to the SE Prealps, Italy. Willdenowia 28: 27-45.

REISCH C. 2002. Climatic oscillations and the fragmentation of plant populations - genetic diversity within and among populations of the glacial relict plants Saxifraga paniculata (Saxifragaceae) and Sesleria albicans (Poaceae). Dissertationes Botanicae, 359. J. Cramer, Berlin, Stuttgart.

REISCH C. 2008. Glacial history of Saxifraga paniculata (Saxifragaceae): molecular biogeography of a disjunct arctic-alpine species from Europe and North America. Bot. J. Linn. Soc. 93: 385-398.

REISCH C., POSCHLOD P., WINGENDER R. 2003. Genetic variation of Saxifraga paniculata Mill. (Saxifragaceae): molecular evidence for glacial relict endemism in central Europe. Bot. J. Linn. Soc. 80: 11-21.
REISCH C., POSCHLOD P. 2004. Clonal diversity and subpopulation structure in central European relict populations of Saxifraga paniculata Mill. (Saxifragaceae) Feddes Repert. 115: 239-247.

SALES E., NEBAUER S.G., MUS M., SEGURA J. 2001. Population genetic study in the Balearic endemic plant species $D i$ gitalis minor (Scrophulariaceae) using RAPD markers. Am. J. Bot. 88: 1750-1759.

SCHAAL B.A., LEVERICH W.J., ROGSTAD S.H. 1991. A comparison of methods for assessing genetic variation in plant conservation biology. In: Falk D.A., Holsinger K.E. (eds). Genetics and conservation of rarc plants, 123-134. Oxford University Press, Oxford.

SCHMIDT K., JENSEN K. 2000. Genetic structure and AFLP variation of remnant populations in the rare plant Pedicularis palustris (Scrophulariaceae) and its relation to population size and reproductive components. Am. J. Bot. 87: 678-689.

SCHNEIDER S., ROESSLI D., EXCOFFIER L. 2000. Arlequin ver. 2.0: A software for population genetic data analysis. Genetics and Biometry Laboratory, University of Geneva.

SCHÖNSWETTER P., STEHLIK I., HOLDEREGGER A., TRIBSCH A. 2005. Molecular evidence for glacial refugia of mountain plants in the European Alps. Mol. Ecol. 14: 3547-3555.

SCHWARTZ M.K., LUIKART G., WAPLES R.S. 2006. Genetic monitoring as a promising tool for conservation and management. Trends Ecol. Evol. 22: 25-33.

SLATKIN M., BARTON N.H. 1989. A comparison of three indirect methods for estimating average levels of gene flow. Evolution 43: 1349-1368.

SMITH J.F., PHAM T.V. 1996. Genetic diversity of the narrow endemic Allium asseae (Alliaceae). Am. J. Bot. 83: 717-726.

SOLTIS P.S., SOLTIS D.E., TUCKER T.L., LANG F.A. 1992. Allozyme variability is absent in the narrow endemic Bensoniella oregona (Saxifragaceae). Conservation Biology 6: 131-134.

SZELĄG Z. 2000. A contribution to the flora of the Kraków-Częstochowa Upland (South Poland). Fragm. Flor. Geobot. Polonica 7: 93-103.

TANSLEY S.A., BROWN C.R. 2000. RAPD variation in the rare and endangered Leucadendron elimense (Proteaceae): implications for their conservation. Biological Conservation 95: 39-48.

van de PEER Y., de WACHTER R. 1994. TREECON for Windows: a software package for the construction and drawing of evolutionary trees for the Microsoft Windows environment. Computer Applications Biosciences 10: 569-570.

VOS P., HOGERS R., BLEEKER M., van de LEE T., HORNES M., FREITERS A., POT J., PELEMAN J., KUIPER M., ZABEAU M. 1995. AFLP: a new technique for DNA fingerprinting. Nucl. Acids Res. 23: 4407-4414.

WRIGHT S. 1969. Evolution and the genetics of populations. Vol. 2: The theory of gene frequencies. University of Chicago Press, Chicago.

WRÓBLEWSKA A., BRZOSKO E., CZARNECKA B., NOWOSIELSKI J. 2003. High levels of genetic diversity in populations of Iris aphylla L. (Iridaceae) an endangered species in Poland. Bot. J. Linn. Soc. 142: 65-72.

WRÓBLEWSKA A., BRZOSKO E. 2006. The genetic structure of the steppe plant Iris aphylla L. at the northern limit of its geographical range. Bot. J. Linn. Soc. 152: 245-255.

YEH, F.C., YANG R.C., BOYLE T.B.J., YE Z.H., MAO J.X. 1997. POPGENE, the user-friendly shareware for population genetic analysis. Molecular Biology and Biotechnology Centre, University of Alberta, Alberta.

ZAWKO G., KRAUSS S.L., DIXON K.W., SIVASITHAMPARAM K. 2001 Conservation genetics of the rare and endangered Leucopogon obtectus (Ericaceae). Mol. Ecol. 10: 2389-2396. 